\title{
AN OVERVIEW OF TECHNOLOGY DRIVEN SOLUTIONS TO THE WATER CRISIS IN DEVELOPING NATIONS
}

Ayush Khanna

Step by Step School, Noida

DOI: 10.46609/IJSSER.2020.v05i05.013 URL:https://doi.org/10.46609/IJSSER.2020.v05i05.013

\begin{abstract}
Developing countries across the world are facing a water crisis due to the growth in population and rapid rates of urbanization. Research suggests that one in nine people in the world do not have access to clean water close to home, and two-thirds of the world's population live in areas of physical water scarcity, where for at least part of the year demand for water exceeds its supply. This has led to public health crises, lower rates of economic development and hampered productivity of individuals. This paper has determined that the worst impact of the water crisis is faced by economically backward sections of developing countries. Technological advancements in the past few decades have paved the way for the development of localized water purification and conservation systems, that are not only cost-effective but also environmentally sustainable. It has been found that the development of these systems has been pioneered by the combined efforts of research groups in educational institutions and global non-profits. This paper has explored the potential of these technologically driven solutions to effect change in developing countries. It has been determined that there is a need for governments in developing countries to invest in and implement decentralized technology-enabled systems of water management to improve the supply of clean and fresh water- a necessity for sustenance and development of individuals and communities.
\end{abstract}

Keywords: Water crisis, Water Scarcity, Water management, Water Treatment

\section{INTRODUCTION}

Fresh Water is considered to be a necessity because it is imperative for personal care and sustenance, commercial agriculture, and other industrial production that sustains the modern economy. Economic development and the rise is the global standard of living has increased the usage of annual demand for water by $1 \%$ since the 1980s (UNESDOC, 2019). The steady rise in 


\section{International Journal of Social Science and Economic Research}

ISSN: $2455-8834$

Volume: 05, Issue: 05 "May 2020"

water usage has been caused by surging demand for freshwater in developing countries that are characterized by an emerging economy and a rapidly growing population. Even though the per capita water use in the majority of these countries remains far below water use in developed countries, the population boom in the developing world has created significant pressure on water resources. Agricultural activities including irrigation, rearing of livestock, and aquaculture account for $69 \%$ of water usage in developing countries (Tebbut, 1998). This is not only due to the high demand for food but also because of the usage of unsustainable methods of water supply. Growing rates of urbanization are likely to reduce agriculture's share of total water usage in comparison with other sectors, but it is expected to remain the largest user of water in terms of both withdrawal and consumption. The population of the developing world has increased an alarming rate over the past few decades which has created immense pressure on the supply of water (Tebbut, 1998).

The 2019 UN World Water Development report notes that about 4 billion people, representing nearly two-thirds of the world population, experience severe water scarcity during at least one month of the year (UNESDOC, 2019). Physical water scarcity occurs when water resources of a particular region are not sufficient to meet the demand for water. Dry regions do not have access to freshwater in lakes or rivers while access to groundwater is often limited. Developed countries have the economic capacity to invest in infrastructure that fills gaps in the water supply. Thus, the regions most affected by this type of water scarcity are a part of the developing world and include Mexico, Northern, and Southern Africa, the Middle East, and India (Sengupta, 2006). Beyond physical unavailability, poor infrastructure for water access, floods and droughts, and the contamination of rivers and large dams are primarily responsible for the lack of availability of water resources in developing countries.

Over one billion people in developing countries have inadequate access to clean water. This significantly hampers personal and community development. Millions of women in these countries are forced to spend hours every day collecting water. The lack of access to fresh water is considered to be a barrier to women's empowerment. It also forces people to consume polluted and contaminated water, which has had a devastating impact on public health (Smith, et. al., 2000). At least 2 billion people use a drinking water source contaminated with feces which leads to the transmission of diseases such as diarrhea, cholera dysentery, typhoid, and polio. 1.8 million children die each year from diarrhea in the developing world (WHO, 2019). The worst impact of this crisis is faced by the underprivileged. In the modern capitalist economy, clean and freshwater is rendered to be a commodity that is only accessible to select sections of ociety. Conventional methods of water management and purification have been unable to cope with the immense pressure on water resources in developing countries. Centralized processing and treatment have proven to be ineffective and expensive (Bharadwaj, 2005). On the other hand, the 


\section{International Journal of Social Science and Economic Research}

ISSN: $2455-8834$

Volume: 05, Issue: 05 "May 2020"

past two decades have been marked with rapid technological developments at a scale comparable to the industrial revolution. This has enabled the development of alternative methods of water management that have the potential to avert the water crisis in the developing world if implemented correctly.

\section{BACKGROUND}

Theoretically, the amount of fresh water accessible to human beings is enough to satisfy the global demand for water. However, individuals' access to freshwater resources is limited due to a plethora of factors such as complex international relations between nation-states and the lack of development of infrastructure concerned with water management (UN Water, 2018). About 60\% of the world's population resides in Asia and the Middle East, yet that area only receives slightly more than a third of the world's water runoff - that is, rainfall or melting snow. Moreover, within countries, there are often huge disparities from region to region, that are amplified by climate change and urbanization (Rekacewicz, 2006). For example - cities like Chennai, which have historically, not been considered to have a 'dry' climate, have faced acute water shortages in recent years (Sugam, et. al., 2017).

The availability of water, and its impacts on the development of nations and individuals, is also affected by wealth. The poorest and most marginalized people have been trapped in a vicious circle. The amount of time spent on procuring water from unsafe sources not only increases the propensity of contracting illnesses that put additional burden on families but also reduces the time that can be spent as economically productive labor. Poorer communities without political influence struggle to persuade authorities and utility companies to provide water services across the developing world (Water Aid, 2019). Wealthier communities, however, are more likely to have reliable water services and are better able to cope with water stress. Drought in Cape Town in 2018 threatened to make it the first modern city to run out of water. Wealthier residents fitted high-tech filters to the 30,000 private boreholes in suburban gardens and bought bottled water, whereas the poorer residents queued at standpipes (Chambers, 2018). Population growth and changes in diet are expected to increase the water demands of agriculture by around $60 \%$ by 2025 (UN Water, 2018). Studies show that conventional methods to tackle the growing demand for water resources have been inadequate in developing countries. Countries like India and Pakistan have been rapidly depleting their groundwater resources. The contamination of groundwater and freshwater resources has further reduced their ability to meet the demand for water in the future (Mekonnen \& Hoekstra, 2016). Research suggests that the water crisis faced by developing countries is exacerbated by improper management, unclear laws, and government corruption. Unchecked pollution that occurs in the form of discharge of industrial and human waste that has rendered the available water practically useless (Mehta, 2012). 


\section{International Journal of Social Science and Economic Research}

ISSN: $2455-8834$

Volume: 05, Issue: 05 "May 2020"

Technological advancement has enabled the development of methodologies that have the potential to solve the impending water crisis. These solutions are not usually funded by governments but are a result of private investment and philanthropy. Even though these solutions have been implemented only in select regions in the recent past, the analysis of their impact can be instrumental in formulating public policy. Scientific developments have allowed the development of filtration devices that can be used by individuals 'on the go'. Even though most of these devices purify water and remove pathogens, their success depends on public awareness and cost-effectiveness (Spinks, 2019). Implementing water management technology like Takadu, which uses data analysis to identify and limit water wastage and pollution is unfeasible in developing countries because of cost intensity (Shah, 2017). Combined research by Carnegie Mellon University and the non-governmental organization 'Water is Life' developed an education and filtration tool in the form of a book. Each page of the book provides basic water and sanitation advice and information. The paper used in the book can be used to purify drinking water and neutralize $99.9 \%$ of bacteria. Each book has enough filtration sheets to provide its reader with clean water for four years. 'Water is Life' has initiated the distribution of these devices in Ghana, Kenya, Haiti, Ethiopia, India, and Tanzania (Spinks, 2019). Combined efforts of non-governmental organizations and research groups promise to fill crucial gaps in water supply and management in developing countries.

\section{DISCUSSION}

About 163 million people in India alone are deprived of clean water. Unless changes are introduced in the present system of water management, this figure is expected to get worse due to increasing urbanization, which leads to the concentration of population in certain parts of a country which puts a significant amount of pressure on water supply (Barua, 2019). Moreover, the dependence on groundwater has led to its overexploitation, and combined with water pollution has significantly reduced the usability and availability of water (Hegde, 2012). Saltwater covers the majority of the earth's surface. However, this saltwater is unfit for consumption. Attempts have been made of developing technologies that convert this saltwater into usable freshwater in a cost-efficient manner. The Sahara Forest Project was launched in Qatar in 2012 and has set up 'Seawater Greenhouses' in Jordan and Tunisia, developing countries with a dry climate, in recent years. Seawater is pumped in from the sea and dripped over a honeycomb structure inside a greenhouse, where it evaporates. The evaporation cools down the indoor environment, while the resulting water vapor condenses on the greenhouse roof, forming freshwater that is fit for consumption and usage (Shah, 2017). Crucial freshwater is often unused due to the presence of contaminants. Western NGOs including 1001 Fontaines have developed solar-powered disinfection technologies that cost-effectively disinfect polluted water. Similarly, the Traveltec Disinfection Reactor, developed in India, uses kinetic energy to release 


\section{International Journal of Social Science and Economic Research}

ISSN: $2455-8834$

Volume: 05, Issue: 05 "May 2020"

shockwaves to eliminate microbes. Evidence Action has installed chlorine dispensers next to wells and water sources in several African countries that allow communities to add chlorine to their water and disinfect it conveniently, and access clean water within 48 hours. Anammox uses special bacteria to remove pollutants from water using less energy, oxygen, and chemicals than other conventional water treatment solutions. The technology can save water treatment plants as much as $60 \%$ in operational costs, while also shrinking their carbon footprint. (Shah, 2017).

Urbanization involves covering huge patches of land with concrete, a non-permeable substance that prevents the replenishment of groundwater. China has launched a plan to implement permeable pavements in all its cities by 2030 to capture $80 \%$ of the rainwater and bring it back into circulation (TWC, 2019). Retas, an NGO operating in India is developing similar drainage systems in Indian cities (Barua, 2019). Fog collection systems are mechanical devices that can be installed in remote locations to extract fresh water out of the fog by condensing it. Developed by VICI Labs and the National Peace Corps Association, WaterSeer uses the surrounding environment to extract water from the atmosphere. It consists of a lower chamber planted six feet below the surface and a turbine that uses wind to spin fan blades. These blades send the air into an internal condensation chamber it cools, allowing water vapor to condense. In ideal conditions, Watersser collects 37 liters of water a day.

Beyond water purification, technology has also opened up avenues that allow better recycling of wastewater and reduce wastage. Moreover reducing the consumption of water is equally important as water purification in the management of limited freshwater resources (Hegde, 2012). The Nano Membrane Toilet, developed by researchers at the Cranfield University and the Bill and Melinda Gates Foundation, is an odorless high-tech toilet that uses no water or external power. Moreover, it turns excrement into water and ash, using the biomatter as an energy source in the process (India Edit Team, 2019). Cost-effective alarm systems have been developed in India that allow households to keep a check on water wastage (Barua, 2019). The introduction of computerized Professional Irrigation Systems reduces the usage of water in agricultural activities. The introduction of solar water pumps in Gujarat, India has enabled farmers to reduce the costs of irrigation and save water (Spinks, 2017). Pipe nozzle fittings called aerators, reduce water flow in domestic taps. Reports suggest that following its introduction in Chennai, an Indian city that faced acute water shortages in 2019, the water consumption by domestic households reduced by $55 \%$ (TOI, 2019). Industrial processes use a significant amount of water which usually goes unnoticed in public policy. For example- each clothing item takes about 2,700 to 10,000 liters of water to produce. The denim brand Levi's has introduced a finishing technique called 'Water Less', that uses 96\% less water than traditional methods. Over the past decade, the company has saved 172 million liters of water whilst manufacturing 13 million products using the Water Less technique (Shah, 2017). 


\section{International Journal of Social Science and Economic Research}

ISSN: $2455-8834$

Volume: 05, Issue: 05 "May 2020"

\section{CONCLUSION}

The provision of clean and fresh water is considered to be the inherent responsibility of modern nation-states since they occupy the position of a parental body over people. Governments in most developing countries have struggled to meet the growing demand for water, especially in urban regions. However, research suggests that the water crisis faced by developing countries is avoidable and is a product of not only a shortage of water resources but also of environmental pollution (Hegde, 2012). The United Nations Water agency (UN-Water) estimates that more than $80 \%$ of the wastewater generated by society flows back into the ecosystem without being treated or reused (UN Water, 2018). The use of conventional and cost-intensive methods of water management along with corruption and mismanagement of funds is responsible for the lack of access and availability of clean and fresh water.

Beyond making state structures more transparent and public officials more accountable there is a need to fundamentally re-design water management systems. There is a need to pivot towards cost-effective localized purification systems that are technologically enabled. Technology has also been instrumental in improving efforts directed towards water conservation and limiting water usage. So far, the success of these initiatives and technologies has been limited because of the lack of outreach and resources amongst NGOs and educational institutions. Local and central governments across the developing world have largely ignored the potential of decentralized systems. There is a need for governments to work alongside grassroots and international level NGOs and research groups in universities to develop and implement cost-effective and sustainable systems of water management.

There exists a social stigma around using recycled material, especially water. The lack of availability and access of people to scientific information perpetuates misconceptions around recycled water. Given that they can afford fresh water even during times of shortage, privileged sections of the society tend to avoid using recycled water, especially if the process is done at the decentralized level. This increases the pressure on water resources- the worst impact of which is faced by the poor and the oppressed. There is a need for state agencies and non-governmental organizations to raise awareness about different water purification techniques to ensure that they are accepted at the community level. The water crisis poses a significant challenge to policymakers, especially in developing countries. The combined efforts of the state, nongovernmental organizations and communities are imperative to ensure that the most oppressed have access to clean and fresh water- a necessity for sustenance and development. 
International Journal of Social Science and Economic Research

ISSN: 2455-8834

Volume: 05, Issue: 05 "May 2020"

\section{BIBLIOGRAPHY}

Barua, A. Quenching Thirst: 5 Brilliant Innovations Helping Indian Cities Save Water. The Better India, 3rd June 2019

Chambers, D. (2018). Day Zero: The city of Cape Town is about to run out of water. The Independent, Accessed on 26th December 2019

Bhardwaj, R.M. (2005). Status of Wastewater Generation and Treatment in India. Working Group on Environment Statistics Joint Work Session on Water Statistics, Accessed on 25th December 2019

Hegde, N.G. (2012). Water Scarcity and Security in India. BAIF Development Research Foundation, Accessed on 27th December 2019

India Edit Team. 'Sponge Cities', and Other Water Innovations That Could Save the World Someday. TWC India, 29th August 2019

Mehta, P. (2012). Impending water crisis in India and comparing clean water standards among developing and developed nations. Scholars Research Library. Accessed on 24th December 2019

Mekonnen, M. \& Hoekstra, A. (2016). Four billion people facing water scarcity. Science Advances. Accessed on 28th December 2019

Rekacewicz, P. (2006). GRID Arendal with UNEP, World's Surface Water: Evaporation and Runoff. Accessed on 24th December 2019

Sengupta, S. (2006). In Teeming India, Water Crisis Means Dry Pipes and Foul Sludge. The New York Times. Accessed on 26th December 2019

Shah, V. 6 water-saving innovations to celebrate this World Water Day. Eco-Business, 22nd March 2017

Spinks, R. Could these five innovations help solve the global water crisis? The Guardian, 13th February 2017

Sugam, R.K., Jain, A., Neog, K. Rethinking wastewater management in India. The Third Pole, 15th May 2019. Accessed on 24th December 2019 
Tebbutt, T. (1998). Principles of Water Quality Control. Elsevier Ltd, Accessed on 25th December 2019

TOI Chennai: New-age technology helps save water. The Times of India. 12th June 209

UNESDOC (2019). The United Nations world water development report 2019: Leaving no one behind, facts and figures. Accessed on 26th December 2019

UN Water (2018). The United Nations world water development report 2018: nature-based solutions for water. Accessed on 24th December 2019

Water Aid. (2019). Beneath the Surface: The State of the World's Water 2019. Accessed on 23rd December 2019

World Health Organization. Drinking-Water. 14th June 2019 